\title{
Epidemiology and health policy: How to avoid becoming prisoners of the proximate
}

\author{
Steinar Westin \\ Department of Public Health and General Practice, Norwegian University of Science and Technology, \\ Trondheim, Norway \\ E-mail: steinar.westin@ntnu.no
}

\begin{abstract}
It goes without saying, epidemiology - the science of distribution of diseases and risk factors in populations - is the basis for all sound and rational health policy. Politicians and people in charge of health services will always be looking for data on the needs for health care in the population, particularly in a welfare state where health services are supposed to be provided according to medical needs and not according to wealth, or "demands" in the market. However, there are two obvious challenges for epidemiology in this respect: 1. It must provide evidence relevant to population health and health policy, and 2. Since health policy is also about health promotion and the prevention of disease, knowledge derived from epidemiology needs some extra concerns and considerations: Epidemiological knowledge is based on data from individuals, while sound preventive measures require strategies for populations. This shift in perspective calls for a good understanding of "causes of the causes", the social determinants for health. There is a risk of being seduced by "the inverse evidence law", suggesting that the best evidence we have is about the simplest but potentially least effective interventions. We have less, or weaker evidence about complex interventions - such as policies. This paradox may lead to the false conclusions that lack of evidence means that there is evidence against an intervention. A true challenge for epidemiology, when providing evidence for health policy, is how to avoid becoming "prisoners of the proximate".
\end{abstract}

This is an open access article distributed under the Creative Commons Attribution Licence, which permits unrestricted use, distribution, and reproduction in any medium, provided the original work is properly cited.

\section{INTRODUCTION}

The emergence of public health, as we think about it in modern societies, was closely linked to the birth of epidemiology, both driven by needs and ambitions in the mid 1800s to control major outbreaks of epidemic diseases. The cholera outbreaks in early urbanized populations in Europe caused great sufferings and fear, and challenged young and creative physicians to think about means and measures to treat the sick, and possibly even prevent the well from becoming sick. We read about it in novels and drama plays, like in Henrik Ibsen's "Enemy of the People" (1). And no Norwegian epidemiologist will ever be unaware of the stories told about the London physician John Snow (1813-58) and his groundbreaking work on the causes and prevention of cholera during the great London epidemics around 1850 , thereby contributing to the birth of modern epidemiology (1).

The emerging understanding of the concepts of contagion and infectious agents happened at a time when states in Europe were becoming stronger and more ambitious in regulating the lives of their citizens (2). Hence social medicine and public health attracted interest and entered the agendas of politicians and governments, as foundations for health policy (3). Public health physicians of Norway still celebrate our first, and very early Public health act ("Sundhetsloven av 1860 "), as the British do with their public health act from 1848 (Fig. 1).

While epidemiology is the natural foundation of public health, the relations of epidemiology to health policy may be more complex, if we understand health policy to mean, as WHO does (4), "decisions, plans, and actions that are undertaken to achieve specific health care goals within a society". It is about the planning and provision of health care and actions taken on a political level to improve or preserve the best health of the population.

The word policy has no precise Norwegian translation, but is more than a national law or health policy that supports a program or intervention. Operational policies, then, are the rules, regulations, guidelines, and administrative norms that governments use to translate national laws and policies into programs and services (4). So, how can epidemiology contribute to health policy?

\section{EVIDENCE BASED HEALTH POLICY}

The simple answer to that question is: providing evidence. In later years it has become an echo within medicine and public health that health policy should be evidence based (5). Who could ever argue against such an obvious statement? However, there is an ongoing discussion in many corners of the medical profession about what evidence means - or rather, what kind of evidence is relevant to medical practice?

In the hierarchy of research providing reliable evidence, we still consider the randomized controlled trials, the RCTs, to be the best. However, complex interventions with relevance to health policy may not easily be subject to such trials, and one may have to resort to less controlled trials, natural experiments or 


\section{RDV}

om

\section{Cumbbedscommisfioner og om Foramftaltninger i stniteoning af epibemiffe og imitionme Sygdomme.}

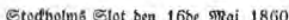

(E) riftiania.

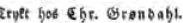

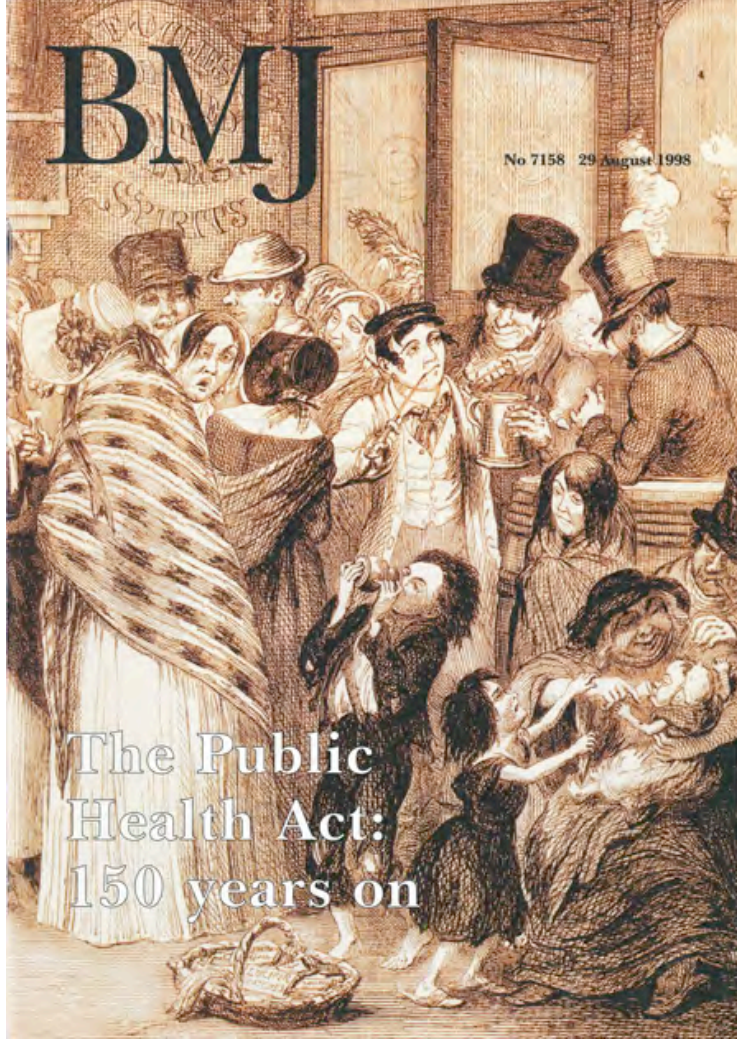

Figure 1. The emergence of public health, in Norway (Sundhetsloven 1860) and England (The Public Health Act 1848) presented by the BMJ in 1998.

more formal quasi-experimental studies, observational studies, or plain comparisons with weaker scientific rigor. Quite often our large population databases will provide the best available evidence, and extracting useful data from them will depend on the skilled application of methods from epidemiology.

The process of synthesizing knowledge and making it useful for public health and health policy requires extensive reviews, and in Norway, as in many other countries, "knowledge centers" have been established with the purpose of providing the "the best available evidence" for clinicians and policymakers. The Norwegian Knowledge Centre for the Health Services was established in 2004, and provides knowledge reviews in a wide area of medical practice, including public health and health policy.

Balancing best available evidence with "most relevant evidence" is a challenge for anyone working on such reviews. The slogan "best available evidence" is most often attributed to the evidence based movement from the 1990s, frequently voiced by its proponents like David Sackett (6). Careful reading of David Sackett's papers will testify to his rather pragmatic view on what kind of evidence is most relevant to address any given health care issue. But within the knowledge hierarchy established in the name of "evidence based", the randomized controlled trials are undisputedly at the top. The Cochrane collaboration all over the world has contributed to this ranking of research, responding collectively to the challenge to medical practice by the now famous Scottish epidemi- ologist Archie Cochrane (1909-88). His main accusation and challenge to health care, voiced in his most famous book from 1972 (7), was that medical practice tends to overlook solid evidence provided from randomized controlled trials. A similar kind of "knowledge movement", the Campbell collaboration, named after the American psychologist Donald Campbell (191696) is preparing and disseminating systematic reviews in social sciences, law and education - some of it relevant to health policy - and has had some influence since its foundation in 1999.

Both of these knowledge movements have undisputedly advanced the critical thinking about evidence for medical practice and health policy. However, the recommendations derived from such knowledge reviews rely heavily on the raw material available - that is, what kind of studies are available and subject to inclusion in systematic reviews. When it comes to contribution from epidemiology, there may presently be two main shortcomings: One is related to the tendency in knowledge reviews to give lower scientific rankings to observational studies (epidemiology) than to RCTs. The other is the tendency within modern epidemiology to be more preoccupied with methods and sophisticated "torturing of data" than studies of the broader determinants of health, a critique voiced repeatedly since the 1990s (8).

We shall have a closer look at one particular case, the role of research based evidence in the formation of a health policy to reduce social inequalities in health in Norway (9). 


\section{Providing EVIDENCE FOR REDUCING SOCIAL INEQUALITIES IN HEALTH}

The white paper on "National Strategy to Reduce Social Inequalities in Health" from 2006 (10) inspired the public health community in Norway to think harder about what kind of policies could really contribute to that aim. As the chairman of the Directorate of Health's "Expert Group to Reduce Social Inequalities in Health" at the time, I had some interesting experience when the whole group was engaged in suggesting means and measures, on any level, to achieve that goal. We initiated a process where all nine members of the group, from a wide range of professions, were challenged to list at least five measures, based on their own professional beliefs and common sense, which everybody did.

Suggestions based on this open process were discussed and placed in a systematic order according to "level of intervention": From the broad national political level, via county or municipal level, measures for local communities or workplaces, the family or the individual, or even measures based on doctors' surgeries.

Next step in the process was to look more thoroughly for any good evidence to support each of the suggested measures, which was definitely harder. What kind of evidence was available to support the effectiveness of each measure, and what kind of adverse effects could be anticipated? For instance from programs for smoking cessation, free school meals for all, increased physical activity in schools, subsidizing the price of fruit and vegetables in Northern Norway, increased taxation of sugar and sweet drinks, safer bicycle roads, earlier closing times for alcohol serving, health promotion groups run by GPs, etc. or - the most controversial but possibly most important - reducing income inequalities (10).

Since epidemiology, sensu stricto, is not an experimental discipline, very few of the suggested measures could be directly supported with strong scientific evidence from epidemiological studies. However, the basic lessons from epidemiology, when analyzing causes of ill health and diseases, provided a common ground for the group's thinking about strategies to reduce health inequalities. At that time our English colleague Michael Marmot had already done a great educational effort to underline the importance of the wider social determinants for health, stressing the importance of understanding "causes of the causes" $(11,12)$. No surprise that Marmot was educated in the tradition of Geoffrey Rose, and that the classic writings of Rose on sick individuals and sick populations still is widely accepted when it comes to strategies for preventive health (13). A central concept in this tradition is that a large number of people with only slightly elevated risk can contribute more to the total burden of disease than the few with a higher risk. Hence, the concept of "population strategy" is well established, shifting the risk curve in a more healthy direction whenever possible, as a contrast to a "high risk strategy", identifying and intervening on high risk individuals (13). Additionally,

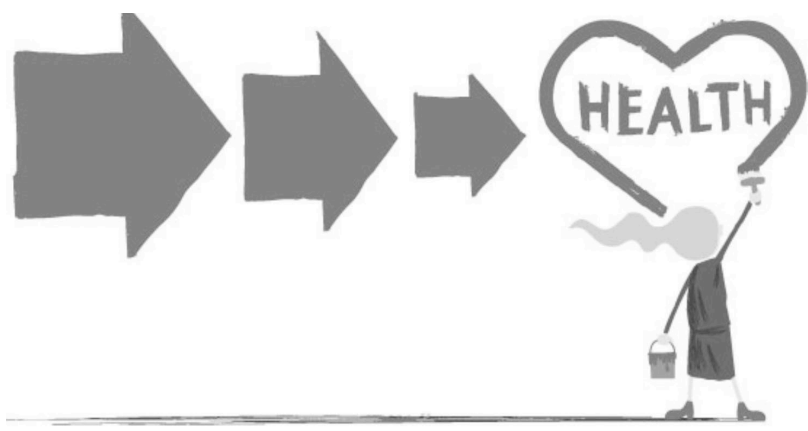

Figure 2. Causes of the causes, or "causal chains". Facsimile from the white paper on "National strategies to reduce social inequalities in health" (10). Causes of health and disease may be addressed at many levels, from decisions on the wider national political level, to local communities, schools and workplaces, to families, and of course individuals as well.

individual risk identification may entail the disadvantage of adding to the "risk epidemic", with its problems of overdiagnosis and overtreatment, and possibly even contributing to "victim blaming". In this perspective "life style factors" is a problematic concept, and should probably be avoided (14).

Within this framework from classic epidemiology, individual risk factors and individual behavior will be seen in a larger context, which was actually underlined in the government's white paper as well (10). The principles of causes of the causes, or causal chains (Fig. 2), were thoroughly explained, which according to our group's experience was much needed in a document aimed at translating research into health policy. Otherwise, the lay public and politicians tend to see the last link in this causal chain only, the individual behavior. In contrast, politicians need to see that causes of disease on the population level may not be the same as in individuals, and that strategies addressing the wider social determinants, like housing, work, distribution of income, and abstract dimensions like trust between people, may be needed, i.e. looking "further up the causal chain". In the end, the white paper recommended a blend of both strategies, suggesting policies both on the population and the individual level $(9,10)$.

\section{WHAT KIND OF EVIDENCE?}

Having agreed on the principles for a health policy to reduce social inequalities in health in our "expert group", the next step was to look for evidence, pros and cons, for effectiveness of our suggested measures. There were already several reports addressing question of social inequalities from the The Norwegian Knowledge Centre for the Health Service available, and we ordered some more.

We had to conclude that epidemiological research did not compete reasonably with the RCTs as basis for health policy recommendations. Actually, based on these knowledge reports, there were rather few recommendations. One central report addressed the 


\title{
St.meld. nr. 20
}

(2006-2007)

\section{Nasjonal strategi for å utjevne sosiale helseforskjeller}

\author{
Tilråding fra Helse- og omsorgsdepartementet av 9. februar 2007, \\ godkjent $i$ statsråd samme dag. \\ (Regjeringen Stoltenberg II)
}

\section{Innledning}

\subsection{Rettferdig fordeling er god folkehelsepolitikk}

Den norske befolkningens helse er god. Men giennomsnittstallene skjuler store, systematiske forskjeller. Helse er ulikt fordelt mellom sosiale grupper i befolkningen. Vi må erkjenne at vi har et lagdelt samfunn - der de som er mest privilegert

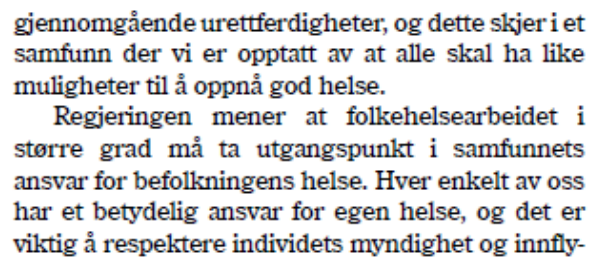

giennomgående urettferdigheter, og dette skjer i et samfunn der vi er opptatt av at alle skal ha like muligheter til å oppnå god helse.

Regjeringen mener at folkehelsearbeidet $i$ større grad må ta utgangspunkt i samfunnets ansvar for befolkningens helse. Hver enkelt av oss har et betydelig ansvar for egen helse, og det er viktig å respektere individets myndighet $\mathrm{og}$ innfly-

Figure 3. The white paper from 2006 presented a rather broad and brave first suggestion in the policy document (10): "A fair distribution is good public health policy".

effects of smoking on social inequalities of health, or more precisely - effect of programs to promote reduced tobacco smoking (15). Not surprisingly, its main conclusion was that such measures would be more effective in high status socio-economic groups than among those with low status, where smoking is already more prevalent. In other words, it could increase rather than decrease smoking among high and low socioeconomic groups.

A later report from 2008 on the effects of promoting more healthy eating and physical activity, "especially among groups with lower socio-economic status" (16), did not provide convincing evidence, because the underlying studies did not have sufficient stratification on effects in various socioeconomic groups. In 2010 we had another knowledge review on effects on health from measures to increase physical activity (17). Having dismissed most studies on the effects of health policy on a societal level as based on weak evidence, the report concluded that the most reliable evidence was based on some RCTs: putting up signposts encouraging people to use the stairs rather than the elevator, campaigns in local communities, and better access to parks and arenas for physical activity "may contribute to a slight increase in physical activity". However, the conclusions were based on the adult population in general, and there was no convincing evidence about effects on parts of the population with previous low levels of physical activity or on immigrants (17). Neither was there any data on the ultimate endpoint, less disease or better health.

If our advice, as an "expert group", to politicians on how to reduce social inequalities in health were to be based on these knowledge reports alone, there would be little advice indeed. However, there was obviously a common understanding among people in the Ministry of Health and Care Services working on the white paper that evidence underpinning health policy had to be based on a broader understanding of knowledge. Relevant in this context is that the white paper was prepared by the Stoltenberg 2 government, a so called "red-green" alliance, which had social equity in health on their political agenda.

My observation was that our "expert group" was impressed by the brave, very first statement in the strategy directly addressing the income distribution in Norway, stating that: "A fair distribution is good public health policy" (10) (Fig. 3).

A series of other policy statements in the white paper suggested measures far beyond what could be 
based on randomized controlled trials or formal knowledge reports alone. It was an eloquent reminder that health policy needs to be shaped on the basis of a much broader understanding of what "knowledge" is $(9,10)$.

Our expert group resorted to a more defensive strategy, and reviewed the policy statements in the white paper (10) according to one important criterion: is there evidence against any of the suggested policies? To our relief (and possibly the Ministry's), we found none.

The most far reaching and possibly most controversial statement in the white paper was "a fair distribution is good public health policy". What kind of evidence could underpin such an ambitious policy, "a fair distribution", at a time when public statistics from almost all European countries showed increasing social disparities in the distribution of income, and even before the Piketty data impressed the world (18)? Is there a direct link to health inequalities? No RCT could ever be expected to address such a broad question.

But of course, we have the broad range of research within social epidemiology: observational studies - yet with ambitions to address a whole range of effects on health from complex social factors (19). Income inequalities are central to this research, and the most influential studies at the time were Richard Wilkinson's use of aggregate data to demonstrate the consistent association between income inequalities and a large number of social and health indicators in various countries or regions (20). Such studies will always be at risk of being confounded by unobserved cultural or societal factors. However, the consistency and robustness of data on these relationships he and his colleague Kate Picket have presented, has convinced most of the research community (21). Or, in Wilkinson's own words during a debate when he visited the Norwegian Directorate of Health: "Better to be approximately right than precisely wrong".

\section{CAN EFFECTS OF UNIVERSAL POLICIES BE EVALUATED?}

A special feature of social security and health policies in the Nordic countries is their universal nature, that is, most of them are designed for all inhabitants (22). This feature makes them generally harder to evaluate than specific programs aimed at parts of the population, because there is not often relevant data for comparisons. This problem is eloquently demonstrated when it comes to data on sick leave in Norway. The lasting disagreements about the validity of cross-national comparisons (23) still give journalists and policymakers a wide range of interpretations, depending on the political "spin" they want to create.

In knowledge reviews on complex social issues, there is a tendency to see results from studies on programs in countries with more fragmented programs and policies being ranked high in "quality". There will most often be randomized studies to be found among them, from some part of the world. There are studies on various interventions for the poor, for unemployed, for immigrants and the homeless, and in some countries even area based randomized trials on the effects of income redistribution. Some early studies are from USA when such questions were still on the political agenda. Indeed, most of these studies seem to come from USA, or in later years also from England, possibly inspired by new research opportunities for comparisons when previously universal programs have been subject to fragmentation or "opting out". When strict criteria for scientific quality are applied in knowledge reviews, such randomized studies tend to be ranked high, even when the social context and political background may be very different from those of Norway or Nordic countries. In other words, they may be lacking in external validity, and any application of them for health policy purposes should be judged critically.

In early phases of work on WHO's Commission on Social Determinants of Health (25), the commission's leader Michael Marmot may have foreseen these problems within the knowledge hierarchy. He was aware of the lack of studies on any effects on health of universal health and social care programs in the Nordic countries, and commissioned a special study by the Swedish research institution CHESS (Centre for Health Equity Studies). Olle Lundberg and coworkers applied a wide variety of analytic methods, cross-sectional comparisons, time series analyses etc., based on national data sets from 18 OECD countries. The report demonstrated the close connection there is between epidemiology and social sciences in such broad studies on effects of health policy. Based on best available data, the report concluded that universal programs did indeed seem to have positive effects on some important indicators of health, like infant mortality, survival in higher age groups, life expectancy in lowest socioeconomic groups etc. A summary of the report was published in The Lancet $(22,25)$, and it remains to be seen how this broad observational study will be evaluated in knowledge reviews.

Within the WHO there have been some initiatives to address this "knowledge problem". In 2010 there was a WHO-sponsored conference in Liverpool on how health equity impact of universal policies can be evaluated (26). The conference report offers extensive discussions on what the participants named the "lifestyle drift", a tendency for research on measures to reduce social inequalities in health to be most preoccupied with life style factors. First of all, such factors are most easily recorded on an individual level. Secondly, epidemiology as a discipline is generally based on individuals as the ultimate and preferred unit for analysis. These inborn characteristics of epidemiology have led some epidemiologists to raise warnings against "becoming prisoner of the proximate" (27), which means being most concerned with the last link in the causal chain of disease (Fig. 2), individual behavior and life style $(14,27)$. 


\section{THE INVERSE EVIDENCE LAW}

Returning to the original question, how can epidemiology contribute to health policy? A great deal, as shown in the case of providing evidence for reducing social inequalities in health. However, the problems with knowledge reviews outlined can be translated into a more general knowledge paradox named "the inverse evidence law" $(28,29)$, referring to a fundamental problem when translating any kind of population based research into actions in public health and health policy: There is generally best evidence for the potentially least important policies (e.g. encourage walking up stairs), and weaker evidence for the potentially most important ones (fair distribution of income).

One of the veterans in epidemiology, Kenneth Rothman, has commented on this problem with a rather straight forward statement: "Generally, the further upstream we move from the occurrence of disease towards root causes, the less secure our inferences about the causal path to disease become" (30). We have to accept that evidence for policies to improve population health will generally be scientifically weaker than what can be expected in clinical medicine, where treatments and interventions are usually better defined and outcomes easier to record.

If scientific criteria from clinical medicine are transferred to public health, an additional fallacy may occur, interpreting lack of evidence for an intervention as evidence against that intervention. A rather recent example is a knowledge review trying to assess any positive effects on reducing social inequalities in health from introducing free school meals for children, which - and probably surprising to foreigners - is not common in Norway (31). Evidence for effects of five different models was evaluated, from the most comprehensive, warm meal served locally in schools, to the simplest, just a free piece of fruit or something "green". There was little evidence for positive effects of any of the comprehensive meals model, but actually a few RCTs suggesting long-term effects on healthier eating habits from providing a free piece of fruit for all.

The report was impressive with its combination of school data, health data and economic cost-effectiveness analyses. However, the lack of evidence on health effects of eating led to a very careful conclusion: only the one-fruit-a-day model could be recommended on the basis of research. When this news had travelled its way through the media, the case for free school meals in Norway was effectively shot down. In our "expert group" we discussed whether anyone had ever done any RCTs on the health effects of for instance marriage, wearing a parachute when jumping from planes, or in fact, of eating.

According to more recent writings, there seems to be an increasing awareness of these fallacies among epidemiologists, as well as among public health officials (26-30): not disregarding relevant research, but accepting a wider concept of what evidence is when applied as foundation for health policy. There is still a case for expert opinion, professional judgement, and previous experience of those affected by the policy. We should remind ourselves about the background and driving forces behind the most important public health and welfare reforms of the last century. Very few of them were conceived or carried out based on undisputable evidence, and definitely not on randomized controlled trials.

\section{CONCLUDING REMARKS}

Epidemiology will continue to be a main source of knowledge for health policy. However, this paper has discussed some crucial concepts to consider and fallacies to avoid. These warnings add to the even more common, but well recognized problem in population based research - and therefore not discussed here interpreting association too easily to mean causation. There is hardly a day when news from medicine and health care cannot be suspected of being prone to this "causation" fallacy.

The discipline of epidemiology, as applied to health policy, is now being challenged from various genomics and "personalized medicine" (32). While public health has traditionally been concerned with interventions at a population level, genomics medicine seem to promote a vision for health care that encourages individualism rather than collectivism. It may have the harmful consequence of undermining the imperative to tackle social and environmental determinants of disease and the collective provision of health care, and even potentially leading to overdiagnosis and overtreatment. However, an increasing number of publications on genetic epidemiology suggest that this field is in vogue.

It remains a challenge indeed, and so does a recent statement from a conference on these issues: "Consequently, the public health community, with its commitment to equity, must take the opportunity to engage with genomic knowledge, ensuring that it advances the population's health" (32).

Yes - a challenge indeed.

\section{REFERENCES}

1. Nylenna M. Dr. Stockmann og dr. Snow - to samfunnsmedisinske helter (Dr Stockmann and dr Snow: two heroes of public health). Tidsskr Nor Legeforen 2003; 123: 3579-81.

2. Moseng OG. Den tidligmoderne staten og ansvaret for undersåttenes helse (The early modern state and the origins of public health in Norway). Tidsskr Nor Legeforen 2000; 120: 2546-7.

3. Fugelli P, Haug K, Høyer G, Westin S. Sosialmedisin - på sporet av det tapte fag. Tidsskr Nor Laegeforen 2000; 120: 3057-61. 
4. World Health Organization. Health Policy (http://www.who.int/topics/health_policy/en/, accessed 22.03.2015).

5. Bjørndal A. Improving social policy and practice: Knowledge matters. Lancet 2009; 373: 1829-31.

6. Sackett D, Rosenberg WMC, Muir Gray JA, Haynes RB, Richardson WS. Evidence based medicine: What it is and what it isn't? It's about integrating individual clinical expertise and the best external evidence. $B M J$ 1996; 312: 71-2.

7. Cochrane AL. Effectiveness and efficiency: Random reflections on health services (2nd edn.). London: Nuffield Provincial Hospitals Trust, 1989.

8. The Lancet (editorial). Putting public health back into epidemiology. Lancet 1997; 350: 229.

9. Giæver $\varnothing$, Torgersen TP. Fra forskning til politikk: Utviklingen av en nasjonal strategi mot sosiale helseforskjeller. I: Mæland JG, Elstad JI, Næss Ø, Westin S (red). Sosial epidemiologi. Sosiale årsaker til sykdom og helsesvikt. Oslo: Gyldendal akademisk, 2009.

10. Report No. 20 (2006-2007) to the Storting. National strategy to reduce social inequalities in health (Norwegian Ministry of Health and Care Services). (St.meld. nr 20 (2006-2007). Nasjonal strategi for å utjevne sosiale helseforskjeller.

11. Marmot M. Social determinants of health inequalities. Lancet 2005; 365: 1099-1104.

12. Marmot M. Achieving health equity: from root causes to fair outcomes. Lancet 2007; 370: 1153-63.

13. Rose G. Sick individuals and sick populations. Int J Epidemiol 2001; 30: 427-32.

14. Vallgårda S. Why the concept "lifestyle diseases" should be avoided. Scand J Public Health 2011; 39: $773-5$.

15. Kunnskapsoppsummering om tiltak for å redusere sosial ulikhet i røyking. Oslo: Kunnskapssenteret, Rapport nr 13-2007, 2007.

16. Kunnskapsoppsummering om kosthold og fysisk aktivitet. Oslo: Kunnskapssenteret, Rapport nr 8-2008, 2008.

17. Kunnskapsoppsummering av fysisk aktivitet. Oslo: Kunnskapssenteret, Rapport nr 19-2010, 2010.

18. Thomas Piketty forklart. Kapitalen i det 21. århundre. Oslo: Spartacus forlag AS, 2014.

19. Mæland JG, Elstad JI, Næss Ø, Westin S (red). Sosial epidemiologi. Sosiale årsaker til sykdom og helsesvikt. Oslo: Gyldendal akademisk, 2009.

20. Wilkinson RG. Unhealthy societies. The afflictions of inequality. London: Routledge, 1996.

21. Wilkinson RG, Pickett K. The Spirit level. Why greater equality makes societies stronger. New York: Bloomsbury Press, 2009.

22. Westin S. Welfare for all - or only for the needy? Lancet 2008; 372: 1609-10.

23. Westin S. Mer meningsfull sykefraværsstatistikk. En utfordring til Statistisk sentralbyrå og NAV. Samfunnsøkonomen 2010; nr. 3: 24-8.

24. WHO Commission for Social Determinants of Health: Closing the gap in a generation. (Verdenskommisjonen for sosiale helsedeterminanter. Utjevne helseforskjellene i løpet av en generasjon.) Genève/Oslo: World Health Organization/Helsedirektoratet («Marmot-kommisjonens» rapport i norsk oversettelse), 2008.

25. Lundberg O, Yngwe MÅ, Stjärne MK, Elstad JI, Ferrarini T, Kangas O, Nordström T, Palme J, Fritzell J, for the NEWS Nordic Expert Group. The role of welfare state principles and generosity in social policy programmes for public health: An international comparative study. Lancet 2008: 372: 1633-40.

26. Milton B, Moonan M, Taylor-Robinson D, Whitehead M (eds). How can the health equity impact of universal policies be evaluated? Liverpool: WHO Collaborating Centre for Policy Research on Social Determinants in Health, 2011.

27. McMichael AJ. Prisoners of the proximate: Loosening the constraints on epidemiology in an age of change. Am J Epidemiol 1999; 149: 887-97.

28. Nutbeam D. How does evidence influence public health policy? Tackling health inequalities in England. Health Promotion Journal of Australia 2003; 143: 154-8.

29. Westin S, Giæver Ø. Loven om den omvendte evidens. I: Larsen Ø, Frøyshov I, Fretheim A, Westin S (red). Medisinsk kunnskap - hvor kommer den fra og hva brukes den til? Oslo: Gyldendal Akademisk, 2012: 160-72.

30. Rothman KJ, Adami H-O, Trichopoulos D. Should the mission of epidemiology include the eradication of poverty? Lancet 1998; 352: 810-3.

31. Skolemåltidet i grunnskolen - kunnskapsgrunnlag, nytte- og kostnadsvirkninger og vurderinger av ulike skolemåltidsmodeller. Rapport fra en arbeidsgruppe nedsatt av Kunnskapsdepartementet. Oslo: Kunnskapsdepartementet, 2006.

32. Boccia S, McKee M. Adany R, et al. Beyond public health genomics: proposals from an international working group. Eur J Publ Health 2014; 24: 876-78. 